\title{
Urgensi Penyatuan Kewenangan Pengujian Peraturan Perundang-undangan oleh Lembaga Peradilan (Judicial Review) Di Indonesia
}

\author{
Safi' \\ Fakultas Hukum Universitas Trunojoyo Madura \\ syafikdidin82@gmail.com
}

\begin{abstract}
Main problems this article is breaking authority of judicial review between Supreme Court and The Constitutional Court as set article 24a paragraph (1) and article 24c paragraph (1) Constitution of Indonesia 1945. This separation authority of judicial review raises legal issues both of philosophical, theoretical, and juridical side. By therefore, integration authority of judicial review by one judiciary is urgent for legal certainty and justice as well as the consequences of recognized theory of hierarchy of legal norms. This study is reviewing legislation as a coherent legal system yang and unwriten law is living in the society.
\end{abstract}

Keywords: integration authority, judicial review, hierarchy of legal norms.

\begin{abstract}
Abstrak
Permasalahan utama yang menjadi fokus adalah pemisahan kewenangan pengujian peraturan perundang-undangan antara Mahkamah Agung dan Mahkamah Konstitusi sebagaimana diatur dalam Pasal 24A ayat (1) dan Pasal 24C ayat (1) UUD NRI 1945. Pemisahan kewenangan pengujian peraturan perundang-undangan ini dapat menimbulkan problem hukum, baik dari sisi filosofis, teoritis, maupun yuridis. Oleh karena itu integrasi kewenangan pengujian peraturan perundang-undangan oleh satu lembaga peradilan menjadi suatu kebutuhan konstitusional yang mendesak guna memberikan jaminan kepastian hukum dan keadilan serta sebagai konsekuensi atas dianutnya teori hirarki norma hukum dalam sistem hukum Indonesia. Penelitian ini penelitian mengkaji peraturan perundang-undangan dalam suatu tata hukum yang koheren serta nilai-nilai hukum tidak tertulis yang hidup dalam masyarakat. Dengan sifat keilmuan hukum yang khas, Penelitian ini beranjak dari telaah hukum positif yang meliputi tiga lapisan dari ilmu hukum, yaitu dogmatik hukum, teori hukum, dan filsafat hukum.
\end{abstract}

Kata kunci: integrasi kewenangan, pengujian peraturan perundang- undangan, hirarki norma hukum.

\section{Pendahuluan}

Setelah Perubahan ke-III UUD NRI

1945, pengaturan pengujian terhadap peraturan perundang-undangan oleh lembaga peradilan (judicial review) menjadi sebuah kajian akademik yang menarik. Selain karena adanya pembentukan lembaga baru yang salah satu kewenangannya adalah menguji konstitusionalitas undang-undang terhadap UUD Tahun 1945 yaitu Mahkamah Kosntitusi, hal tersebut juga karena tidak lagi memusatnya kekuasaan negara hanya pada satu cabang kekuasaan negara yaitu Presiden atau eksekutif. Sehingga norma hukum atau 
peraturan perundang-undangan di bawah Undang-Undang Dasar Tahun 1945 saat ini banyak yang dimohonkan pengujian ke Mahkamah Agung dan ke Mahkamah Konstitusi. Keadaan ini positif, dalam rangka untuk dapat lebih memberikan jaminan perlindungan terhadap hak-hak warga Negara yang dijamin oleh konstitusi, sebab tidak sedikit materi/isi dari peraturan perundang-undangan yang merugikan hak-hak warga negara yang dijamin dalam konstitusi.

Setelah dilakukan Perubahan Ketiga terhadap UUD 1945 tersebut, tepatnya pada tanggal 19 November 2001, maka kewenangan untuk menguji peraturan perundang-undangan diberikan kepada dua lembaga pelaksana kekuasaan kehakiman, yaitu kepada Mahkamah Agung untuk menguji peraturan perundang-undangan di bawah undangundang sesuai dengan ketentuan Pasal 24A ayat (1) UUD NRI 1945, dan kepada Mahkamah Konstitusi untuk menguji undang-undang terhadap UUD NRI 1945, sebagaimana diatur dalam Pasal 24C ayat (1) UUD NRI 1945. Jadi dengan perubahan ketiga ini, kewenangan kekuasaan kehakiman untuk melakukan pengujian peraturan perundang-undangan diperkuat dan dipertegas legitimasi yuridisnya, jika sebelumnya hanya diatur melalui undang-undang, yaitu UU No. 14 tahun
1970 tentang Kekuasaan Kehakiman dan Perubahannya, saat ini langsung diatur dalam Konstitusi/UUD NRI 1945. Jika sebelumnya hanya peraturan perundangundangan di bawah undang-undang yang dapat diuji, tetapi sekarang undang-undang pun dapat di uji konstitusionalitasnya oleh Mahkamah Konstitusi.

Walaupun demikian, kemajuan dalam pengaturan pengujian peraturan perundang-undangan ini bukan berarti tanpa suatu permasalahan. Permasalahan utama yang akan menjadi fokus penelitian ini adalah pemecahan kewenangan pengujian peraturan perundang-undangan antara Mahkamah Agung dan Mahkamah Konstitusi sebagaimana diatur dalam Pasal 24A ayat (1) dan Pasal 24C ayat (1) UUD NRI 1945. Karena sesungguhnya jenis dan hirarki peraturan perundangundangan Indonesia, berada dalam satu kesatuan sistim yang integral sesuai dengan teori norma hukum, yaitu teori Stufenbau De Recht atau The Hirarchi of Law Theory dari Hans kelsen. Artinya antara satu jenis dan hirarki peraturan perundang-undangan yang satu dengan yang lainnya terjalin satu kesatuan nilai yang saling mendasari, sampai pada suatu nilai tertinggi yang disebut dengan grudnorm (Kelsen) atau staat fundamental norm (Nawiaski) yang 
selanjutnya dituangkan dalam UU No. 12 Tahun 2011 tentang Pembentukan Peraturan Perundangan-undangan. (Lihat ketentuan Pasan 7 UU No. 12 Tahun 2011 tentang Pembentukan Peraturan Perundang-undangan)

Dengan demikian, menurut sistim hukum Indonesia, peraturan perundangundangan atau hukum tertulis itu disusun dalam suatu tingkatan yang disebut hirarki peraturan perundangundangan. Tata urutan menunjukkan tingkat-tingkat dari masing-masing bentuk yang bersangkutan, yaitu yang disebut lebih dahulu mempunyai kedudukan lebih tinggi dari pada bentuk-bentuk yang disebut belakang (dibawahnya). Di samping itu, tata urutan mengandung konsekuensi hukum bentuk peraturan atau ketetapan yang tingkatannya lebih rendah tidak boleh mengandung materi yang bertentangan dengan materi yang dimuat di dalam suatu peraturan yang bentuknya lebih tinggi, terlepas dari soal siapakah yang berwenang memberikan penilaian terhadap materi peraturan serta bagaimana nanti konsekuensi apabila suatu peraturan itu materinya dinilai bertentangan dengan materi peraturan yang lebih tinggi (Ni'matul Huda, 2005: 50). Hal ini selaras dengan asas hukum lex superiori derogate legi inferiori (hukum yang lebih tinggi mengalahkan hukum yang tingkatannya di bawahnya). Ini semua dimaksudkan agar tercipta kepastian hukum dalam sistim peraturan perundang-undangan.

Oleh karena itu, pemisahan kewenangan dibidang judicial review antara Mahkamah Agung dan Mahkamah Konstitusi tersebut, telah menimbulkan problem baik secara filosofis, teoritis, maupun yuridis. Secara filosofis pemisahan kewenangan tersebut berdampat pada tidak tercapainya tujuan hukum serta mengacaukan satu kesatuan sistem nilai dalam peraturan perundang-undangan, secara teoritis pemisahan kewenangan tersebut bertentangan dengan teori negara hukum, teori politik hukum, teori norma hukum, dan teori pengujian norma hukum. Sedangkan secara yuridis dapat menimbulkan konflik putusan antara Mahkamah Agung dan Mahkamah Konstitusi (conflict of norm) serta dapat menimbulkan kesan bahwa Mahkamah Konstitusi kedudukannya lebih tinggi daripada Mahkamah Agung.

Dari uraian tersebut diatas, maka dapat diambil rumusan permasalah sebagai berikut: mengapa diperlukan penyatuan kewenangan pengujian peraturan perundang-undangan oleh satu lembaga peradilan? Bagaimana rumusan konsepnya serta lembaga peradilan mana yang ideal diberi kewenangan 
dalam pengujian peraturan perundangundangan?

\section{Metode Penelitian}

Jenis penelitian ini merupakan penelitian hukum normatif, yaitu penelitian yang mengkaji peraturan perundang-undangan dalam suatu tata hukum yang koheren serta nilai-nilai hukum tidak tertulis yang hidup dalam masyarakat. Dengan sifat keilmuan hukum yang khas, penelitian/pengkajian hukum (rechtsbeoefening) jenis ini beranjak dari telaah hukum positif yang kajiannya meliputi tiga lapisan dari ilmu hukum, yaitu dogmatik hukum, teori hukum, dan filsafat hukum. Sifat khas (sui generis) keilmuan hukum normatif oleh D.H.M. Meuwissen dicirikan dengan: 1) sifat empiris-analitis, yaitu memberikan pemaparan dan menganilisis tentang isi dan struktur hukum, 2) sistematisasi gejala-gejala hukum, 3) menginterpretasi hukum yang berlaku, 4) menilai hukum yang berlaku, dan 5) arti praktis dari ilmu hukum yang berkaitan erat dengan dimensi normatif (D.H.M. Meuwissen, 1985 : 446-447).

\section{Hasil Dan Pembahasan}

Pemisahan kewenangan pengujian peraturan perundang-undangan antara Mahmakah Agung dan Mahkamah Konstitusi sebagaimana diatur dalam
Pasal 24A ayat (1) dan Pasal 24C ayat (1) UUD Tahun 1945 tidaklah ideal karena dapat menimbulkan problem hukum yang rumit, baik dari sisi filosofis, teoritis, maupun yuridis sebagaimana diuraikan dalam latar belakang diatas. Oleh karena itu integrasi kewenangan pengujian peraturan perundang-undangan oleh satu lembaga peradilan (Mahkamah Konstitusi) menjadi suatu kebutuhan konstitusional yang mendesak dalam rangka untuk memberikan jaminan kepastian hukum dan keadilan serta sebagai konsekuensi atas dianutnya teori hirarki norma hukum dalam sistem hukum Indonesia.

\section{Landasan Filosofis, Teoritis, dan Yuridis.}

Secara filosofis, pada hakekatnya jenis dan hirarki peraturan perundangundangan Indonesia, berada dalam satu kesatuan sistim nilai yang integral sesuai dengan teori norma hukum, yaitu teori Stufenbau De Recht atau The Hirarchi of Law Theory dari Hans kelsen. Artinya antara satu jenis dan hirarki peraturan perundang-undangan yang satu dengan yang lainnya terjalin satu kesatuan nilai yang saling mendasari, sampai pada suatu nilai tertinggi yang disebut dengan grudnorm (Kelsen) atau staat fundamental norm (Nawiaski) atau 
Pancasila yang selanjutnya dituangkan dalam UU No. 12 Tahun 2011 tentang Pembentukan Peraturan Perundanganundangan. (Lihat ketentuan Pasan 7 UU No. 12 Tahun 2011 tentang Pembentukan Peraturan Perundangundangan)

Pancasila dan Pembukaan UUD 1945 dianggap sebagai norma dasar, sebagai sumber hukum positif. Rumusan hukum dasar dalam pasal-pasal yang terdapat pada badan (batang rubuh) UUD 1945 adalah pancaran dari norma yang ada dalam Pembukaan UUD 1945 dan Pancasila. Asas-asas Pancasila terkandung dalam dan merupakan bagian dari Pembukaan UUD 1945, sehingga dengan menyebut Pembukaan UUD 1945 saja, asas-asas itu akan dengan sendirinya telah tercakup. Penjelasan UUD 1945 sendiri juga telah mengutarakan hal yang serupa, walaupun tidak menggunakan istilah norma dasar, melainkan dengan menyebutnya sebagai "cita-cita hukum (rechtsidee)" yang terwujud dari pokokpokok pikiran yang terkandung dalam Pembukaan UUD 1945, "yang menguasai hukum dasar negara, baik hukum yang tertulis (undang-undang dasar), maupun hukum yang tidak tertulis". selain disebut sebagai cita-cita hukum, bagi pembukaan UUD 1945 ini ada istilah lain yang digunakan" yaitu
Grundnorm dan Staatsfundamentalnorm (Usep Ranuwijaya, 1983 : 175) atau "pokok kaidah fundamental Negara", seperti digunakan oleh Notonagoro. (Notonagoro, 1974 : 9 dan 44)

Secara teoritik, dalam prespektif teori negara hukum, dalam suatu negara hukum yang demokratis haruslah memenuhi unsur-unsur atau prinsipprinsip tertentu dari sutau negara hukum. Prinsip atau unsur yang relevan untuk diterapkan dalam penyatuan/integrasi kewenangan pengujian peraturan perundangundangan adalah the supremacy of law atau supremasi hukum dan perlindungan terhadap hak-hak asasi manusia. Dalam prinsip supremasi hukum, hukum harus berada diatas segala kekuasaan lainnya, dan oleh karena itu maka hukum harus dapat memberikan jaminan kepastian hukum dan keadilan. Dan hal tersebut sangat berpotensi tidak dapat dicapai, jika kewenangan pengujian peraturan perundang dipisah antara Mahkamah Agung dan Mahkamah Konstusi.

Dalam prespektif teori konstitusi materi peraturan perundang-undangan harus berdasar dan bersumber dari konstitusi. Dan untuk menjamin bahwa materi dan nilai-nilai dari konstitusi itu dipatuhi oleh norma-norma yang berada dibawahnya, maka diperlukan mekanisme pengujian konstitusional 
yang dilakukan oleh lembaga peradilan (judicial review).

Sedangkan dari prespektif teori wewenang, walaupun wewenang Mahkamah Agung dan Mahkamah Konstitusi dalam bidang pengujian peraturan perundang-undangan samasama bersumber dari konstitusi (atribusi), akan tetapi teori wewenang ini akan dipakai untuk menganalisis bobot dari wewenang tersebut dikaitkan dengan latar belakang dan tujuan dari dibentuknya lembaga peradilan tersebut, sehingga dengan demikian dapat ditentukan lembaga peradilan mana yang lebih tepat diberi wewenang dibidang pengujian peraturan perundang-undangan, yaitu dalam hal ini adalah Mahkamah Konstitusi.

Dari prespektif teori politik hukum, pemisahan kewenangan pengujian peraturan perundang-undangan tersebut tidak didasari oleh politik hukum yang jelas untuk kepentingan strategis kehidupan berbangsa dan bernegara, melainkan hanya didasarkan pada alasan tehnis dan praktis karena Mahkamah Agung mulai sebelum perubahan UUD Tahun 1945 sudah memiliki kewenangan dalam pengujian peraturan perundang-undangan dibawah undangundang. Padahal seharusnya perumusan suatu kebijakan hukum (legal policy) didasarkan pada cita-cita dan kepentingan strategis kehidupan berbangsa dan bernegara. Sehingga dengan integrasi kewenangan pengujian peraturan perundang-undangan dalam satu lembaga peradilan dimaksudkan untuk dapat menjaga dan mensingkronkan nilai-nilai konstitusi dalam materi peraturan perundangundangan dibawahnya.

Sedangkan dalam prespektif teori norma hukum, tata urutan peraturan perundang-undangan dapat dikaitkan dengan ajaran Hans Kalsen mengenai Stufenbau des Rech atau The Hierarchy of Law ang berkaitan bahwa kaidah hukum merupakan suatu susunan berjenjang dan setiap kaidah hukum yang lebih rendah bersumber dari kaidah yang lebih tinggi. Hukum itu adalah sah (Valid) apabila dibuat oleh lembaga atau otoritas yang berwenang membentuknya dan berdasarkan norma yang lebih tinggi sehingga dalam hal ini norma yang lebih rendah (inferior) dapat dibentuk oleh norma yang lebih tinggi (superior), dan hukum itu berjenjang-jenjang dan berlapis-lapis membentuk hiarki, dimana suatu norma yang lebih rendah berlaku, bersumber, dan berdasar pada norma yang lebih tinggi, norma yang lebih tinggi berlaku, bersumber dan berdasar pada norma yang lebih tinggi lagi, demikian seterusnya sampai pada suatu norma yang tidak dapat di telusuri lebih 
lanjut dan bersifat hipotesis dan fiktif, yaitu norma dasar (grundnorm) (Usep Ranuwijaya, 1983 : 175). Dengan demikian, seharusnya lembaga peradilan yang diberikan kewenangan untuk melakukan judicial review cukup satu lembaga peradilan, agar dapat lebih menjamin satu kesatuan sistem nilai yang terkandung dalam muatan materi peraturan perundang-undangan.

Konsekuensi penting dari prinsipprinsip hirarki norma hukum harus diadakan mekanisme yang dapat menjaga dan menjamin agar prinsip tersebut tidak disimpangi atau dilanggar. Mekanismenya dalam prespektif teori pengujian norma hukum (teori pengujian peraturan perundang-undangan) yaitu adalah sistem pengujian hukum (toetsingrecht atau review) atas setiap peraturan perundang-undangan, atau kebijakan maupun tindakan pemerintahan lainnya., terhadap peraturan perundang-undangan yang lebih tinggi tingkatannya atau tingkat tertinggi yaitu UUD dan harus dilakukan oleh satu lembaga peradilan yang putusannya berfisat final dan mengikat. Tanpa konsekuensi tersebut, tata urutan tidak akan berarti.

Sedangkan secara yuridis/normatif, pemisahan kewenangan pengujian peraturan perundang-undangan antara Mahkamah Agung dan Mahkamah
Konstitusi akan berdampak pada ketidak adanya jaminan kepastian hukum, serta ketidak efektifan dalam proses pelaksanaan pengujian peraturan perundang-undangan itu sendiri. Karena bisa jadi seseorang warga Negara yang merasa haknya dirugikan oleh terbitnya suatu peraturan perundang-undangan dibawah undang-undang sehingga mengajukan gugatan/permohonan hak uji materiil kepada Mahkamah Agung dan gugatannya dikabulkan, tetapi diwaktu yang sama atau setelahnya ada warga Negara lainnya mengajukan permohonan judicial review terhadap undang-undang yang menjadi dasar terbitnya peraturan tersebut kepada Mahkamah Konstitusi dan permohonannya dikabulkan, maka kondisi seperti ini akan menimbulkan ketidak pastian hukum bagi warga Negara yang pertama tersebut, serta berpotensi menimbulkan problem hukum yang cukup rumit, selain tidak efisiennya sistem pengujian peraturan perundang-undangan tersebut. Selain itu integrasi kewenangan pengujian peraturan perundang-undangan pada satu lembaga peradilan akan dapat menjamin kesetaraan kedudukan antara Mahkamah Agung dan Mahkamah Konstitusi. 
tentang Perubahan atas Undang-

Konsep Integrasi Kewenangan Pengujian Peraturan Perundangundangan oleh Satu Lembaga Peradilan.

Sebagaimana ketentuan Pasal 24

ayat (2) UUD Negara Republik Indonesia Tahun 1945 yang mengatur bahwa pengorganisasian kekuasaan kehakiman saat ini diberikan kepada dua lembaga negara, yaitu Mahkamah Agung dan Mahkamah Konstitusi. Untuk membedakan posisi, tugas, fungsi, dan wewenang kedua lembaga kekuasaan kehakiman tersebut diatur secara limitatif dalam Pasal 24A ayat (1) Pasal 24C ayat (1) UUD Negara Republik Indonesia Tahun 1945.

Penjabaran dari ketentuanketentuan tentang tugas dan fungsi kedua lembaga kekuasaan kehakiman tersebut selanjutnya diatur dalam Pasal 10 ayat (1), (2) dan (3) UU No. 23 Tahun 2003 tentang Mahkamah Konstitusi, sebagaimana telah diubah dengan UU No. 8 Tahun 2011; Pasal 11 ayat (2) dan (3) UU No. 4 Tahun 2004 tentang Kekuasaan Kehakiman (Saat ini ketentuan Pasal 11 ayat (2) dan (3) sudah diganti dengan ketentuan Pasal 18 UU No. 48 Tahun 2009 tentang Kekuasaan Kehakiman) dan Pasal 31 ayat (1) sampai dengan ayat (5) dan Pasal 31A ayat (1) sampai dengan ayat (7) UU No. 5 Tahun 2004
Undang Nomor 14 Tahun 1985 tentang Mahkamah Agung.

Pengaturan pengujian peraturan perundang-undangan dalam UU No. 24 Tahun 2003 dapat dilihat pada pasal yang mengatur tentang kewenangan dan kewajiban yang melekat pada Mahkamah Konstitusi sebagaimana yang diatur dalam Pasal 10 ayat (1) dan ayat (2) UU No. 24 Tahun 2003 adalah sebagai berikut:

(1) Mahkamah Konstitusi berwenang mengadili pada tingkat pertama dan terakhir yang putusannya bersifat final untuk:

a. menguji undang-undang terhadap UUD Negara RI Tahun 1945,

b. memutus sengketa kewenangan lembaga negara yang kewenangannya diberikan oleh UUD Ncgara RI Tahun 1945;

c. memutus pembubaran partai politik;

d. memutus perselisihan tentang hasil pemilihan umum.

(2) Mahkamah Konstitusi wajib memberikan putusan atas pendapat DPR bahwa presiden dan/atau wakil presiden diduga telah melakukan pelanggaran hukum berupa pengkhianatan terhadap negara, korupsi, penyuapan, tindak pidana berat lainnya, atau perbuatan tercela, dan/ atau tidak lagi memenuhi syarat 
sehagai presiden dan/atau wakil presiden sebagaimana dimaksud dalam UUD Negara RI Tahun 1945.

Oleh karena itu, munculnya Mahkamah Konstitusi yang secara kelembagaan merupakan lembaga negara yang kedudukannya sederajat dengan lembaga negara lainnya dan pengaturannya diatur dalam UUD Negara RI Tahun 1945 dan UU No. 24 Tahun 2003 jo. UU No. 8 Tahun 2011, merupakan bagian dari upaya kontrol yudisial terhadap penyelenggaraan negara melalui mekanisme hukum. Mekanisme kontrol oleh lembaga kekuasaan kehakiman merupakan bagian penting dalam upaya membangun dan mengembangkan prinsip negara demokrasi berdasar atas hukum atau negara hukum yang demokratis. Dengan begitu, Indonesia pasca perubahan ketiga UUD NRI Tahun 1945 menganut paham supremasi konstitusi.

Demikian pula Undang-Undang Nomor 4 Tahun 2004 tentang Kekuasaan Kehakiman merupakan unifikasi dari Undang-Undang Nomor 14 Tahun 1970 dan Undang-Undang Nomor 35 tahun 1999 tentang Perubahan UU No. 14 Tahun 1970. Terbitnya UU No. 4 Tahun 2004 merupakan konsekuensi hukum atas perubahan UUD Negara RI Tahun
1945 di bidang kekuasaan kehakiman, yaitu Pasal 24 ayat (2), Pasal 24A ayat (1), dan Pasal 24C ayat (1). Secara normatif, pengujian peraturan perundang-undangan juga diatur dalam Undang-Undang Nornor 4 T'ahun 2004, yaitu dalam Pasal 2, Pasal 11 ayat (2) huruf b, dan Pasal 12 ayat (1) huruf a, sebagaimana telah diubah dengan UU No. 48 Tahun 2009 tentang Kekuasaan Kehakiman.

Pasal 18 UU No. 48 Tahun 2009 mengatur bahwa, "Kekuasaan kehakiman sebagaimana dilakukan oleh sebuah Mahkamah Agung dan badan peradilan yang berada di bawahnya dalam lingkungan peradilan umum, lingkungan Peradilan agama, lingkungan peradilan militer, lingkungan peradilan tata usaha negara, dan oleh sebuah Mahkamah Konstitusi". Sedangkan dalam Pasal 20 ayat (2) huruf b UU No. 48 Tahun 2009 diatur sebagai berikut; "Mahkamah Agung mempunyai kewenangan: ...menguji peraturan perundang-undangan di bawah undangundang terhadap undang-undang...".

Adapun yang berkaitan dengan kewengan Mahkamah Konstitusi diatur dalam Pasal 29 ayat (1) huruf a UU No. 48 Tahun 2009, yaitu sebagai berikut; "Mahkamah Konstitusi berwenang mengadili pada tingkat pertama dan terakhir yang putusannya bersifat final 
untuk: a. Menguji undang-undang terhadap Undang-Undang Dasar Negara Republik Indonesia Tahun 1945”, dst.

Demikian pula dalam UndangUndang Nomor 5 Tahun 2004 tentang Perubahan Undang-Undang Nomor 14 Tahun 1985 tentang Mahkamah Agung, dapat dilihat pada Pasal 31 ayat (1), (2), (3), (4), dan (5) sebagai berikut.

(1) Mahkamah Agung mempunyai wewenang menguji peraturan perundang-undangan di bawah undangundang terhadap undang-undang.

(2) Mahkamah Agung menyatakan tidak sah peraturan perundang-undangan di bawah undang-undang atas alasan bertentangan dengan peraturan perundang-undangan yang lebih tinggi atau pembentukannya tidak memenuhi ketentuan yang berlaku.

(3) Putusan mengenai tidak sahnya peraturan perundang-undangan sebagaimana dimaksud pada ayat (2) dapat diambil baik berhubungan dengan pemeriksaan pada tingkat kasasi maupun berdasarkan permohonan langsung pada Mahkamah Agung.

(4) Peraturan perundang-undangan yang dinyatakan tidak sah sehagaimana dimaksud pada ayat (3) tidak mempunyai kekuatan hukum mengikat;
(5) Putusan sebagaimana dimaksud pada ayat (3) wajib dimuat dalam Berita Negara Republik Indonesia dalam jangka waktu paling lambat 30 (tiga puluh) hari kerja sejak putusan diucapkan.rundangundangan dibawah undangundang terhadap undang-undang dan kewenangan Mahkamah Konstitusi RI untuk pengujian undang-undang terhadap UUD NRI 1945.

Tetapi bila dilihat dari prespektif filosofis, teoritis dan yuridis sebagaimana telah diuraikan dalam landasan filosofis, teoritis, dan normatif di atas, rumusan konsep kewenangan pengujian peraturan perundangundangan yang dipisah antara manjadi kewenangan Mahkamah Agung dan kewenangan Mahkamah Konstitusi adalah tidaklah ideal, karena berpotensi menimbulkan persoalan bagi dari aspek filosofis, teoritis, maupun yuridisnya sebagaimana telah diuraikan dalam pembahasan-pembahasan terdahulu.

Apabila ditelaah secara seksama, perumusan Pasal 24A ayat (1) dan Pasal 24C ayat (1) UUD Negara Republik Indonesia Tahun 1945 dari prespektif teori politik hukum telah menunjukkan adanya kesungguhan untuk memberikan peluang berkembangnya kontrol normatif 
terhadap berhagai produk hukum sebagai keputusan politik agar terjaga konsistensi dan harmonisasi normatif produk hukum secara hierarkis. Akan tetapi, ketika mengorganisasikan pengujian peraturan perundangundangan dipisah antara menjadi kewenangan Mahkamah Agung untuk pengujian peraturan perundangundangan terhadap undang-undang, dan menjadi kewenangan Mahkamah Konstitusi untuk pengujian undangundang terhadap undang-undang dasar, tujuan atau politik hukum tersebut berpotensi tidak tercapai. Karena antara putusan Mahkamah Agung dan putusan Mahkamah Konstitusi berpotensi menimbulkan perbedaan (conflict of norm) karena tolok ukur/parameter serta pertimbangan hukum yang digunakan juga berbeda.

Menurut Jimly, pembagian tugas di bidang pengujian peraturan (judicia review) atas peraturan perundangundangan antara MA dan MK sama sekali tidak ideal, karena dapat menimbulkan perbedaan atau putusan yang saling bertentangan antara MK dan MA. Kedepan, memang harus dipikirkan kemungkinan mengintegrasikan seluruh sistem pengujian peraturan di bawah kewenangan MK. Ada empat alasan yang menyebabkan pemisahan pengujian peraturan tersebut menjadi tidak ideal, yaitu sebagai berikut:

1) Pemberian kewenangan pengujian (Judicial Review) materi undangundang terhadap Undang-undang dasar kepada MK yang baru dibentuk mengesankan hanya sebagian tambahan perumusan terhadap materi UUD secara mudah dan tambal sulam, seakan-akan konsepsi hak uji materiil peraturan yang ada di tangan MA tidak turut berpengaruh dengan hak uji yang diberikan kepada MK. perumusan demikian terkesan seakan kurang didasarkan atas pendalaman konseptual berkenaan dengan konsepsi uji materi itu sendiri secara komprehensif.

2) Pemisahan kewenangan itu masuk akal untuk dilakukan jika sistem kekuasaan yang di anut masih didasarkan atas prinsip pembagian kekuasaan sebagaimana yang dianut oleh UUD 1945 sebelum mengalami perubahan pertama dan kedua, UUD 1945 setelah perubahan telah resmi dan tegas menganut prinsip pemisahan kekuasaan horizontal mengutamakan prinsip checks and balances. Oleh karena itu, pemisahan antara materi undangundang dan materi peraturan di 
bawah undang-undang tidak UUD Negara RI Tahun 1945, maupun seharusnya dilakukan lagi.

3) Dalam praktik pelaksanaannya nanti, secara hipotetis dapat timbul pertentangan substantif antara putusan MA dengan putusan MK. Oleh karena itu, sebaiknya sistem pengujian peraturan perundangundangan di bawah konstitusi diintegrasikan saja dii bawah MK. Dengan demikian masing-masing Mahkamah dapat memfokuskan perhatian pada masalah yang berbeda. MA menangani persoalan keadilan dan ketidakadilan bagi warga negara, sedangkan MK menjamin konstitusionalitas keseluruhan peraturan perundangundangan.

4) Jika kewenangan pengujian materi peraturan di bawah UUD sepenuhnya diberikan kepada MK, tentu beban MA dapat dikurangi (Jimly Asshiddiqie, 2002 : 40-41).

Oleh karena itu menurut Zainal Arifin Hoesein (Zainal Ariffin Hoesein, 2009 : 317-318), secara kelembagaan perlu segala bentuk pengujian peraturan perundang-undangan disentralisasikan dalam satu lembaga negara, seperti dipraktikkan di negara Federal Jerman. Sentralisasi kelembagaan fungsi pengujian peraturan perundangundangan baik undang-undang terhadap peraturan di bawah undang-undang terhadap undang-undang dimaksudkan agar fungsi pengujian peraturan perundang-undangan dapat dijalankan secara efektif dan efisien, di samping untuk menghindarkan konftik hukum. Sebab, pengaturan pengujian yang masih dibedakan subjek dan objeknya sebagaimana yang ditegaskan dalam Pasal 24A dan Pasal 24C UUD Negara RI Tahun 1945, dapat memberikan tafsir bahwa posisi MK lebih tinggi dibanding dengan MA, padahal dalam UUD Negara RI Tahun 1945 kedua lembaga negara tersebut memiliki kedudukan yang sama hanya tugas dan fungsinya yang berbeda.

Pemisahan objek dan subjek pengujian peraturan perundangundangan sebagaimana yang diatur dalam Pasal 24A ayat (1) dan Pasal 24C ayat (1) UUD Negara RI Tahun 1945 mengandung kelemahan dalam pelaksanaannya. Sebab apabila terjadi perbedaan keputusan terhadap objek yang diuji yang memiliki keterkaitan normatif secara vertikal, maka akan dapat menimbulkan kekacauan baik segi pelaksanaan putusan, maupun segi tertib hukum. Pembedaan objek pengujian adalah hanya berkaitan lembaga yang diberikan kewenangan untuk melaksanakannya. Dengan demikian, 
perlu diakhiri pembedaan objek pengujian peraturan perundangundangan, yakni seluruh peraturan perundang-undangan di bawah undangundang dasar terhadap undang-undang dasar menjadi objek pengujian oieh Mahkamah Konstitusi, dengan tolok ukur pengujiannya adalah mulai dari UUD tahun 1945 (Konstitusi) dan semua peraturan perundang-undangan yang lebih tinggi dari obyek (peraturan perundang-undangan) yang diuji.

Dengan demikian, kedepan setelah melihat praktik yang berlangsung di Indonesia pasca amandemen UUD NRI Tahun 1945, pengujian peraturan perundang-undangan yang dibedakan obyek dan subyeknya perlu dirumuskan kembali yaitu mengintegrasikan kewenangan pengujian peraturan perundang-undangan dibawah satu atap Mahkamah Konstitusi, sebagaimana yang dipraktekkan di Negara Federal Jerman, Austria, dan Hungaria, dengan kombinasi yang sesuai dengan sistem hukum Indonesia.

Sehingga rumusan ketentuan Pasal 24A ayat (1) dan Pasal 24C ayat (1) UUD Negara Republik Indoensia Tahun 1945, yang semula berbunyi:

Pasal 24A ayat (1):

Mahkamah Agung berwenang mengadili pada tingkat kasasi, menguji peraturan perundang-undangan dibawah undang- undang terhadap undang-undang, dan mempunai wewenang lainnya yang diberikan oleh undang-undang.

Pasal 24C ayat (1):

Mahkamah Konstitusi berwenang mengadili pada tingkat pertama dan terakhir yang putusannya bersifat final untuk menguji undang-undang terhadap Undang-undang Dasar, memutus sengketa kewenangan lembaga negara yang kewenangannya diberikan oleh Undang-undang Dasar, memutus pembubaran partai politik, dan memutus perselisihan tentang hasil pemilihan umum.

Dari ketentuan tersebut diatas, jika dicermati secara seksama, selain persoalan pemisahan kewenangan dibidang pengujian peraturan perundangundangan yang tidak ideal, juga menimbulkan problem hukum berupa kekosongan hukum (vacuum of norm), yaitu dalam ketentuan Pasal 24A ayat (1) UUD Tahun 1945 menimbulkan kekosongan hukum, berupa: bagaimana jika peraturan perundang-undangan dibawah undang-undang tersebut tidak bertentangan dengan undang-undang, tetapi bertentang dengan peraturan perundang-undangan yang lebih tinggi dari peraturan perundang-undangan yang dimintakan untuk diuji? Sedangkan dalam ketentuan Pasal 24C ayat (1) UUD Tahun 1945 menimbulkan kekosongan 
hukum, yaitu: bagaimana jika yang bertentangan dengan konstitusi/UUD adalah peraturan perundang-undangan dibawah undang-undang?

Idealnya dirubah dengan menintegrasikan kewenangan pengujian peraturan perundang-undangan menjadi kewenangan satu lembaga peradilan yaitu Mahkamah Konstitusi dengan tolok ukur pengujian adalah peraturan perundangundangan yang kedudukannya mulai satu tingkat lebih tinggi dari obyek yang diuji sampai dengan peraturan perundangundangan tertinggi, yaitu UUD Negara Republik Indonesia Tahun 1945, sehingga rumusannya menjadi sebagai berikut:

Pasal 24A ayat (1):

Mahkamah Agung berwenang mengadili pada tingkat kasasi dan mempunai wewenang lainnya yang diberikan oleh undang-undang.

Sedangkan rumusan Pasal 24C ayat (1) menjadi:

Mahkamah Konstitusi berwenang mengadili pada tingkat pertama dan terakhir yang putusannya bersifat final untuk menguji undang-undang dan peraturan perundang-undangan dibawahnya terhadap Undang-undang Dasar dan/atau terhadap peraturan perundang-undangan yang lebih tinggi tingkatannya, memutus sengketa kewenangan lembaga negara yang kewenangannya diberikan oleh Undangundang Dasar, memutus pembubaran partai politik, dan memutus perselisihan tentang hasil pemilihan umum.

Selain dari perubahan ketentuan tersebut, dapat pula dilakukan melalui kegiatan penafsiran terhadap ketentuan Pasal 24A ayat (1) dan Pasal 24C ayat (1) UUD Tahun 1945, yaitu dengan mengartikan kata 'undang-undang' dalam Pasal 24C ayat (1) sebagai wet in materiele zin atau undang-undang dalam arti materiel yaitu mencakup undangundang dan seluruh peraturan perundangundangan yang dibawahnya, serta memperluas makna Undang-undang Dasar dalam pasal tersebut yaitu mencangkup Mulai dari UUD dan seluruh peraturan perundang-undangan yang kedudukannya lebih tinggi dari peraturan perundang-undangan yang dimintakan untuk diuji. Adapun terkait dengan kewenangan Mahkamah Agung dibidang judicial review sebagaimana dimaksud dalam Pasal 24 ayat (1) UUD Tahun 1945 harus ditafsirkan sebagai bagian kewenangan MA dalam penangan perkara konkrit atau Mahkamah Agung menyerahkan dan melimpahkan penanganan perkara dibidangan judicial review kepada Mahkamah Konstitusi.

Perubahan rumusan ketentuan dalam Pasal 24A ayat (1) dan Pasal 24C ayat (1) UUD Tahun 1945 tersebut, untuk 
selanjutnya tentunya harus diikuti perubahan ketentuan dalam UndangUndang tentang Kekuasaan Kehakiman, Undang-Undang tentang Mahkamah Agung, dan Undang-Undang tentang Mahkamah Konstitusi, serta beberapa peraturan teknis lainnya.

\section{Mahkamah Konstitusi sebagai Lembaga Ideal Pelaksana Pengujian Peraturan Perundang-undangan (judicial review) di Indonesia.}

Setelah diuraikan mengapa perlu integrasi/penyatuan kewenangan pengujian peraturan perundangundangan oleh satu lembaga peradilan yaitu Mahkamah Konstitusi sebagaimana telah dijelaskan di atas, selanjutnya muncul pertanyaan, mengapa perlu disatukan dibawah kewenangan Mahkamah Konstitusi?

Menurut Jimly Asshiddiqie sebagaimana telah diuraikan diatas, bahwa ada empat alasan yang menyebabkan pemisahan pengujian peraturan tersebut menjadi tidak ideal. Sedangkan dalam prespektif teori wewenang, teori politik hukum dan teori pengujian norma hukum, pilihan penyatuan kewenangan pengujian peraturan perundang-undangan dibawah Mahkamah Konstitusi, juga didasari oleh beberapa alasan hukum sebagai berikut: Pertama, untuk mengurangi beban/tumpukan pekerjaan penanganan perkara di MA yang luar biasa banyaknya. Sehingga dengan diintegrasikannya kewenangan pengujian peraturan perundangundangan dibawah Mahkamah Konstitusi, diharapkan Mahkamah Agung akan lebih fokus pada penanganan perkara konkrit ditingkat kasasi dan peninjauan kembali bagi para pencari keadilan (teori wewenang dan politik hukum).

Kedua, untuk memberikan kepastian dan keadilan kepada masyarakat karena tidak aka ada lagi perbedaan penafsiran atau putusan yang saling bertentangan antara Mahkamah Agung dan Mahkamah Konstitusi (teori politik hukum). Ketiga, akan lebih efisien dan efektif dari segi waktu penyelenggaraan pengujiannya. Sehingga tidak perlu lagi ada pengaturan larangan bagi Mahkamah Agung untuk menguji suatu peraturan dibawah undang-undang manakala di Mahkamah Konstitusi sedang diuji undang-undang yang berkaitan dengan peraturan yang akan diujikan di Mahkamah Agung sebagaimana diatur dalam Pasal 55 UU No. 24 Tahun 2003 tentang Mahkamah Konstitusi, serta akan dapat lebih menjamin harmonisasi materi peraturan perundang-undangan melalui mekanisme kontrol normatif (teori pengujian norma hukum). Selain itu, 
Menurut hasil penelitian disertasi Zainal Arifin Hoesein, dilihat dari segi praktis efisien dan efektivitas, justru pengujian peraturan perundang-undangan oleh Mahkamah Agung berjalan sangat tidak efektif, karena rata-rata perkara yang diselesaikan per tahun antara 1.-2 (gugatan) dan 3 perkara (permohonan). Sebaliknya, Mahkamah Konstitusi justru lebih produktif, karena hanya dalam 1 (satu) tahun 1 (satu) bulan dapat menyelesaikan 22 (dua puiuh dua) perkara (Zainal Ariffin Hoesein, 2009 : 311-312).

Keempat, karena dari prespektif teori wewenang dan teori politik hukum, tujuan dibentuknya serta tugas dan fungsi utama Mahkamah Konstitusi sebagaimana dijelaskan dalam Penjelasan Umum UU No. 24 Tahun 2003 tentang Mahkamah Konstitusi adalah untuk menangani perkara ketatanegaraan atau perkara konstitusi tertentu dalam rangka konstitusi agar dilaksanakan secara bertanggungjawab sesuai kehendak rakyat dan cita-cita demokrasi. Keberadaan MK sekaligus untuk menjaga terselenggaranya pemerintahan negara yang stabil, dan juga merupakan koreksi terhadap pengalaman kehidupan ketatanegaraan di masa lalu yang ditimbulkan oleh tafsir ganda terhadap konstitusi. Oleh karena itu, Mahkamah Konstitusi selain sebagai penjaga konstitusi (the guardian of the constitution), Mahkamah Konstitusi juga merupakan penafsir tertinggi konstitusi (the sole interpreter of constitution).

Kelima, karena hukum acara pengujian peraturan perundangundangan di Mahkamah Konstitusi lebih terbuka dibanding dengan hukum acara pengujian peraturan perundangundangan di Mahkamah Agung, yaitu dengan melibatkan dan mengundang pemohon, termohon, dan pihak terkait dalam setiap tahapan persidangan.

\section{Simpulan}

Dari uraian tersebut diatas, dapat diambil suatu kesimpulan bahwa pemisahan kewenangan pengujian peraturan perundang-undangan antara Mahkamah Agung dan Mahkamah Konstitusi adalah tidak ideal dan berpotensi menimbulkan problem hukum yang sangat rumit, baik dari sisi potensi terjadinya konflik putusan antara kedua lembaga peradilan tersebut, juga menimbulkan kerancuan kesetaraan kedudukan antara Mahkamah Agung dan Mahkamah Konstitusi. Sehingga kedepan perlu dirumuskan ulang dengan mengintegrasikan kewenangan pengujian peraturan perundangundangan kepada Mahkamah Konstitusi dengan tolok ukur pengujian adalah mulai dari peraturan perundangundangan yang lebih tinggi sampai pada 
konstitusi baik melalui perubahan atau penafsiran ketentuan Pasal 24A ayat (1) dan Pasal 24C ayat (1) UUD Tahun 1945.

\section{Daftar Pustaka}

\section{Buku}

Abdul Mukthie Fadjar, 2006, Hukum Konstitusi dan Mahkamah Konstitusi, Jakarta: Sekretariat Jenderal dan Kepaniteraan Mahkamah Konstitusi.

Bagir Manan, 2004, Teori dan Politik Konstitusi, Yogyakarta: FH UII Press, cetakan kedua.

D.H.M. Meuwissen, 1985, In Apeldoom's Inleiding Tot de Studie van het Nederlandse Recht, W.E.J. Tjeenk Zwolle.

Hans Kelsen, 1971, General Theory of Law and State, translate by Andres Wedberg, New York : Russel \& Russel.

Jimly Asshiddiqie, 2002, Konsolidasi Naskah UUD 1945 setelah Perubahan Keempat, Jakarta: PSHTN FH UI.

Jimly Asshiddiqie, 2004, Kontitusi dan Konstitusionalisme Indonesia, Jakarta, Mahkamah Konstitusi RI dan Pusat Studi Hukum Tata Negara Fakultas Hukum UI.

Mauro Cappelleti, 1979, Judicial Review in the Contemporary World, the Bobbs-Merril Company Inc.

Moh. Mahfud MD, 1998, Politik Hukum di Indonesia, Jakarta: LP3ES.

\section{Ali Safa'at, 2006, Teori Hans Kelsen} tentang Hukum, Jakarta:
Sekretariat Jendral dan Kepaniteraan Mahkamah Konstitusi RI.

Notonagoro, 1974, Pancasila Dasar Falsafah Negara, Jakarta: Pantjuran Tujuh.

Ni'matul Huda, 2005, Negara Hukum, Demokrasi dan Yudicial Review, Yogyakarta: UII Press.

Usep Ranuwijaya, 1983, Hukum Tata Negara Indonesia, Dasardasarnya, Jakarta: Ghalia Indonesia.

Zainal Ariffin Hoesein, 2009, Judicial Review di Mahkamah Agung RI, Tiga Dekade Pengujian Peraturan Perundang-undangan, Jakarta: Raja Grafindo Grafika.

\section{Peraturan Perundang-undangan:}

Undang Undang Dasar Negara Republik Indonesia Tahun 1945

Undang Undang Nomor 24 Tahun 2003 tentang Mahkamah Konstitusi.

Undang Undang Nomor 48 Tahun 2009 tentang Kekuasaan Kehakiman dan beberapa UU tentang Kekuasaan Kehakiman sebelumnya.

Undang-Undang Nomor 3 Tahun 2009 tentang Mahkamah Agung dan bebarapa UU tentang Mahkamah Agung sebelumnya.

Undang Undang Nomor 12 Tahun 2011 tentang Pembentukan Peraturan Perundang-undangan.

Peraturan Mahkamah Konstitusi Nomor 6/PMK/ 2005 Tentang Pedoman Beracara dalam Perkara Pengujian Undang-Undang. 
Peraturan Mahkamah Agung Nomor 1

Tahun 2011 tentang Hak Uji

Materiil. 